\title{
Combined Influence of Stack Height and Exit Velocity on Dispersion of Pollutants Caused by Helwan Cement Factory (Study using AERMOD Model)
}

\author{
Nabil. H. Amer \\ Civil Engineering Department \\ Military Technical College \\ Cairo, Egypt
}

\author{
Abbas A. Abbas \\ Civil Engineering Department \\ Military Technical College \\ Cairo, Egypt
}

\begin{abstract}
The cement industry plays a very important role in the growth of the national economy and the social development of any country. Therefore, severe restrictions and controls must be placed on cement industry to assess the environmental impacts of such projects not only before implementation but also during and after the operation of these projects. This research is about to introduce and build model using AERMOD model that can be used in environmental impact assessment of cement factories considering the effect of the stack height and exit gas velocity with one, two and three stacks, on the dispersion and the concentration of air emissions at receptor locations. The air dispersion model is used to predict the dispersion of particulate matter $\left(\mathrm{PM}_{10}\right)$ and sulphur dioxide $\left(\mathrm{SO}_{2}\right)$ emissions released from cement plant stack. Finally, the model showed that the stack heights and exit velocity are controlling factors in pollutant dispersion, where the relation between the stack height and the exit velocity against the maximum pollutant concentrations is inversely proportional.
\end{abstract}

Moreover, this model was applied to a current cement plant located $30 \mathrm{Km}$ south of Cairo. The emission concentrations from cement plant (8lines) were found to be less than the limits of Egyptian and International Environmental Laws. However, the emission concentrations from the cement plant when operated with full capacity (10lines) were found to violate the limits" without background reading".

\section{General Terms}

Environmental Management.

\section{Keywords}

Air dispersion models, Exit velocity, Stack height, Air pollution

\section{INTRODUCTION}

The main environmental impacts in the manufacture of cement are related to the following categories [1]:

1. Dust from stack emissions and fugitive sources.

2. Gaseous atmospheric emissions of $\mathrm{NO}_{\mathrm{x}}, \mathrm{SO}_{2}, \mathrm{CO}_{2}$, VOC and others:

3. Other emissions like noise and vibrations, odour, process water, waste production, etc.

4. Resources consumption of energy and raw materials.

There are several competing requirements in the design of an air pollution model. A model must capture the essential physics of the dispersion process and provide reasonable and repeatable estimates of downwind concentrations. This generally requires detailed knowledge of meteorological conditions, source/emission parameters, and land use/terrain information [2].

\subsection{Terrain data}

Land use information and terrain elevations are important input parameters in the dispersion modeling analysis. The rate at which a plume disperses and eventually reaches ground level is affected by the degree of urbanization of the surrounding area. Generally, greater plume dispersion is found in urban environments due to enhanced mechanical and thermal turbulence. Land use within the vicinity of the facility is used to determine whether the area should be viewed as urban or rural. Additionally, terrain information is input to the model [2]. This data is used to establish the base elevation of onsite structures including buildings and the stack. It is also used to establish the elevation of receptors where pollutant concentrations are to be predicted.

\subsection{Meteorological data}

Meteorological data is used by the model to help simulate plume transport and dispersion. Data quantifying the wind direction and speed, ambient temperature, pressure, precipitation, clouds and humidity are used as input to the model[2].

\subsection{Source/Emission parameters}

Define how the emissions are released into the atmosphere. For pollutants that are vented from stacks, emission information needed by models are: [3]

\section{Stack configurations}

a. Number of stack and distributions in the site layout

b. The stack, height and diameter

2. Pollutant configurations

a. Type of pollutant.

b. Emission rates of the pollutant.

c. The temperature and velocity of the pollutant exiting the stack.

The parameters studied are stack height and exit gas velocity with one, two and three stacks, on the dispersion and the concentration of air emissions at receptor locations. An air dispersion model is used to predict the dispersion of particulate matter $\left(\mathrm{PM}_{10}\right)$ and sulphur dioxide $\left(\mathrm{SO}_{2}\right)$ emissions released from cement plant stack[4]. The air dispersion model used in this modeling study is AERMOD[5].

\section{APPLIED MODEL (AERMOD):}

AERMOD was used to study the effects of stack height (varying from 80 to $140 \mathrm{~m}$ with interval $10 \mathrm{~m}$ ) and exit gas velocity (varying from 15 to $25 \mathrm{~m} / \mathrm{s}$ with interval $5 \mathrm{~m} / \mathrm{s}$ ) in case of one, two and three stacks on the dispersion and the 
concentration of air emissions at receptor locations using urban dispersion option during the period of 1 st three months of 2009.

\subsection{Terrain Data:}

The terrain data is in the form of Digital Elevation Model (DEM) data that is available from the USGS-DEM (U.S. Geological Survey). The receptor grid has specified covering an area of $14 \times 14$ sq. $\mathrm{km}$ with $200 \mathrm{~m}$ resolution [6].

\subsection{Meteorological Data:}

AERMOD requires steady and horizontally homogeneous hourly surface and upper air meteorological observations for simulating the dispersion. In the absence of meteorological observations at an hourly interval, the use of regional model derived meteorological parameters is well suited[7]. However,

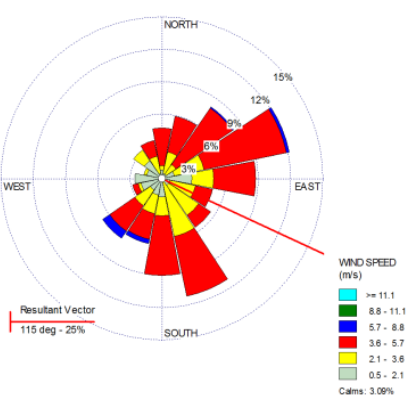

January-2009

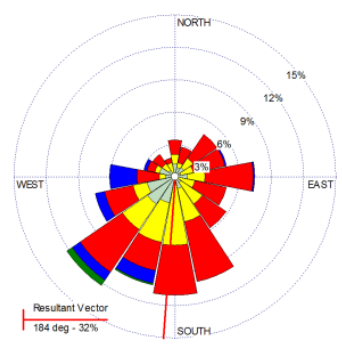

February - 2009 meteorological observations with such frequency are not available for Helwan city (as is the case with most locations in Egypt). To overcome this difficulty, the required meteorological parameters are derived from prognostic high resolution simulations using a regional Mesoscale Model for creating weather forecasts and climate projections ( MM5) model outputs and create the AERMOD meteorological input file by-passing the need for AERMET and thus any observational data requirement[8].

MM5 model is integrated for the period 1st January to 31st March 2009 using time step of 60 seconds. Angular distribution of wind directions and wind class frequency distribution for the entire period simulated by MM5 is as shown in Figure 1and Figure 2.

Figure1: Angular distribution of wind directions as simulated by MM5

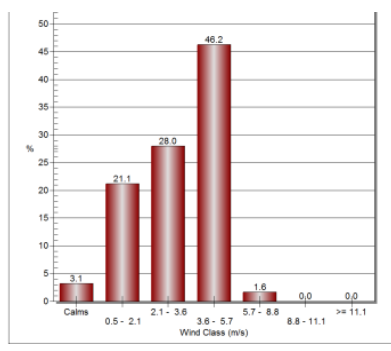

January-2009

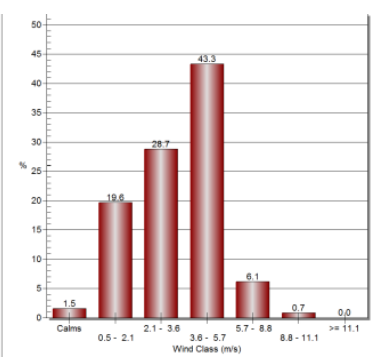

February - 2009

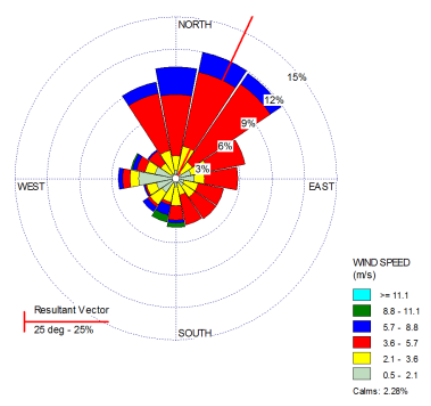

March-2009

Figure 2: Wind Class Frequency Distribution as simulated by MM5

\subsection{Input Source Characteristics}

In order to study the effect of stack height and exit velocity on contaminant dispersion and concentration in case of one, two and three stack, AERMOD model was used to predict the dispersion of total suspended particulates $\left(\mathrm{PM}_{10}\right)$ and sulphur dioxide $\left(\mathrm{SO}_{2}\right)$ emissions released from an industrial source.

\subsubsection{Study the effect of increasing stack height}

In order to study the effects of stack height on contaminant dispersion and concentration, a total of four model runs (increased stack height from $80 \mathrm{~m}$ to140m with interval $20 \mathrm{~m}$ ) were completed. The emission stack data for the four model runs as shown in Table 1, Table 2and Table 3[9].

Table 1. Emission stack data for the four model runs in case of one stack.

\begin{tabular}{|c|c|c|c|c|c|c|}
\hline Run & $\begin{array}{c}\text { SH } \\
\mathbf{m}\end{array}$ & $\begin{array}{c}\text { SD } \\
\mathbf{m}\end{array}$ & $\begin{array}{c}\mathbf{T} . \\
\mathbf{K}\end{array}$ & $\begin{array}{c}\mathbf{V} \\
\mathbf{m} / \mathbf{s}\end{array}$ & $\begin{array}{c}\mathbf{S O}_{\mathbf{2}} \\
\mathbf{t / y}\end{array}$ & $\begin{array}{c}\mathbf{P M}_{\mathbf{1 0}} \\
\mathbf{t / y}\end{array}$ \\
\hline $\mathbf{1}$ & 80 & 3.55 & 395 & 15 & 1558.5 & 662.3 \\
\hline $\mathbf{2}$ & 100 & 3.55 & 395 & 15 & 1558.5 & 662.3 \\
\hline
\end{tabular}

\begin{tabular}{|l|l|l|l|l|l|l|}
\hline $\mathbf{3}$ & 120 & 3.55 & 395 & 15 & 1558.5 & 662.3 \\
\hline $\mathbf{4}$ & 140 & 3.55 & 395 & 15 & 1558.5 & 662.3 \\
\hline
\end{tabular}

Table 2. Emission stack data for the four model runs in case of two stack.

\begin{tabular}{|c|c|c|c|c|c|c|c|c|}
\hline \multirow[b]{2}{*}{$\mathbf{N}$} & \multicolumn{2}{|c|}{ Coordinate } & \multirow{2}{*}{$\begin{array}{c}\text { SH } \\
\mathbf{m}\end{array}$} & \multirow{2}{*}{$\begin{array}{c}\text { SD } \\
\text { m }\end{array}$} & \multirow{2}{*}{$\begin{array}{l}\mathbf{T} . \\
\mathbf{K}\end{array}$} & \multirow{2}{*}{$\begin{array}{c}\mathbf{V} \\
\mathbf{m} / \mathbf{s}\end{array}$} & \multirow{2}{*}{$\begin{array}{c}\mathbf{S O}_{2} \\
\mathbf{t} / \mathbf{y}\end{array}$} & \multirow{2}{*}{$\begin{array}{c}\mathbf{P M}_{10} \\
\mathbf{t} / \mathbf{y}\end{array}$} \\
\hline & $\begin{array}{l}\mathbf{X} \\
\mathbf{m}\end{array}$ & $\begin{array}{l}\mathbf{Y} \\
\mathbf{m}\end{array}$ & & & & & & \\
\hline \multirow[b]{2}{*}{1} & 0 & 50 & 80 & 3.55 & 395 & 15 & 1558.5 & 662.3 \\
\hline & 0 & -50 & 80 & 3.55 & 395 & 15 & 1558.5 & 662.3 \\
\hline \multirow[b]{2}{*}{2} & 0 & 50 & 100 & 3.55 & 395 & 15 & 1558.5 & 662.3 \\
\hline & 0 & -50 & 100 & 3.55 & 395 & 15 & 1558.5 & 662.3 \\
\hline \multirow{2}{*}{3} & 0 & 50 & 120 & 3.55 & 395 & 15 & 1558.5 & 662.3 \\
\hline & 0 & -50 & 120 & 3.55 & 395 & 15 & 1558.5 & 662.3 \\
\hline \multirow[b]{2}{*}{4} & 0 & 50 & 140 & 3.55 & 395 & 15 & 1558.5 & 662.3 \\
\hline & 0 & -50 & 140 & 3.55 & 395 & 15 & 1558.5 & 662.3 \\
\hline
\end{tabular}




\subsubsection{Study the effect of increasing exit velocity at different stack height:}

In order to study the effects of exit velocity on contaminant dispersion and concentration at different height (stack height from $80 \mathrm{~m}$ to $140 \mathrm{~m}$ with interval $20 \mathrm{~m}$ ), a total of three model runs (increased exit velocity from $15 \mathrm{~m} / \mathrm{s}$ to $25 \mathrm{~m} / \mathrm{s}$ with interval $5 \mathrm{~m} / \mathrm{s}$ ) were completed as shown in Table 4, Table 5and Table 6.

Table3. Emission stack data for the four model runs in case of three stack.

\begin{tabular}{|c|c|c|c|c|c|c|c|c|}
\hline & \multicolumn{2}{|c|}{ Coordinate } & \multirow[b]{2}{*}{$\begin{array}{c}\text { SH } \\
\text { m }\end{array}$} & \multirow[b]{2}{*}{$\begin{array}{c}\text { SD } \\
\text { m }\end{array}$} & \multirow[b]{2}{*}{$\begin{array}{l}\text { T. } \\
\mathbf{K}\end{array}$} & \multirow[b]{2}{*}{$\begin{array}{c}\mathbf{V} \\
\mathbf{m} / \mathbf{s}\end{array}$} & \multirow[b]{2}{*}{$\begin{array}{c}\mathbf{S O}_{2} \\
\mathbf{t} / \mathbf{y}\end{array}$} & \multirow[b]{2}{*}{$\begin{array}{c}\mathbf{P M}_{10} \\
\mathbf{t} / \mathbf{y}\end{array}$} \\
\hline & $\begin{array}{l}\mathbf{X} \\
\mathbf{m}\end{array}$ & $\begin{array}{l}\mathbf{Y} \\
\mathbf{m}\end{array}$ & & & & & & \\
\hline \multirow{3}{*}{1} & 0 & 100 & 80 & 3.55 & 395 & 15 & 1558.5 & 662.3 \\
\hline & 0 & 0 & 80 & 3.55 & 395 & 15 & 1558.5 & 662.3 \\
\hline & 0 & -100 & 80 & 3.55 & 395 & 15 & 1558.5 & 662.3 \\
\hline \multirow{3}{*}{2} & 0 & 100 & 100 & 3.55 & 395 & 15 & 1558.5 & 662.3 \\
\hline & 0 & 0 & 100 & 3.55 & 395 & 15 & 1558.5 & 662.3 \\
\hline & 0 & -100 & 100 & 3.55 & 395 & 15 & 1558.5 & 662.3 \\
\hline \multirow{3}{*}{3} & 0 & 100 & 120 & 3.55 & 395 & 15 & 1558.5 & 662.3 \\
\hline & 0 & 0 & 120 & 3.55 & 395 & 15 & 1558.5 & 662.3 \\
\hline & 0 & -100 & 120 & 3.55 & 395 & 15 & 1558.5 & 662.3 \\
\hline \multirow{3}{*}{4} & 0 & 100 & 140 & 3.55 & 395 & 15 & 1558.5 & 662.3 \\
\hline & 0 & 0 & 140 & 3.55 & 395 & 15 & 1558.5 & 662.3 \\
\hline & 0 & -100 & 140 & 3.55 & 395 & 15 & 1558.5 & 662.3 \\
\hline
\end{tabular}

Table 4. Emission stack data for the three model runs in case of one stack.

\begin{tabular}{|c|c|c|c|c|c|c|}
\hline Run & $\begin{array}{c}\text { SH } \\
\mathbf{m}\end{array}$ & $\begin{array}{c}\mathbf{S D} \\
\mathbf{m}\end{array}$ & $\begin{array}{c}\mathbf{T} . \\
\mathbf{K}\end{array}$ & $\begin{array}{c}\mathbf{V} \\
\mathbf{m} / \mathbf{s}\end{array}$ & $\begin{array}{c}\mathbf{S O}_{\mathbf{2}} \\
\mathbf{t / y}\end{array}$ & $\begin{array}{c}\mathbf{P M}_{\mathbf{1 0}} \\
\mathbf{t / y}\end{array}$ \\
\hline $\mathbf{1}$ & 80 & 3.55 & 395 & 15 & 1558.5 & 662.3 \\
\hline $\mathbf{2}$ & 80 & 3.55 & 395 & 20 & 1558.5 & 662.3 \\
\hline $\mathbf{3}$ & 80 & 3.55 & 395 & 25 & 1558.5 & 662.3 \\
\hline
\end{tabular}

Table 5. Emission stack data for the three model runs in case of two stack.

\begin{tabular}{|c|c|c|c|c|c|c|c|c|}
\hline & \multicolumn{2}{|c|}{ Coordinate } & \multirow[b]{2}{*}{$\begin{array}{c}\text { SH } \\
\text { m }\end{array}$} & \multirow[b]{2}{*}{$\begin{array}{c}\text { SD } \\
\mathbf{m}\end{array}$} & \multirow[b]{2}{*}{$\begin{array}{l}\mathbf{T} . \\
\mathbf{K}\end{array}$} & \multirow[b]{2}{*}{$\begin{array}{c}\mathbf{V} \\
\mathbf{m} / \mathbf{s}\end{array}$} & \multirow[b]{2}{*}{$\begin{array}{c}\mathrm{SO}_{2} \\
\mathrm{t} / \mathbf{y}\end{array}$} & \multirow[b]{2}{*}{$\begin{array}{c}\mathbf{P M}_{10} \\
(\mathbf{t} / \mathbf{y})\end{array}$} \\
\hline & $\begin{array}{l}\mathbf{X} \\
\mathbf{m}\end{array}$ & $\begin{array}{l}\mathbf{Y} \\
\mathbf{m}\end{array}$ & & & & & & \\
\hline \multirow{2}{*}{1} & 0 & 50 & 80 & 3.55 & 395 & 15 & 1558.5 & 662.3 \\
\hline & 0 & -50 & 80 & 3.55 & 395 & 15 & 1558.5 & 662.3 \\
\hline \multirow{2}{*}{2} & 0 & 50 & 80 & 3.55 & 395 & 20 & 1558.5 & 662.3 \\
\hline & 0 & -50 & 80 & 3.55 & 395 & 20 & 1558.5 & 662.3 \\
\hline \multirow{2}{*}{3} & 0 & 50 & 80 & 3.55 & 395 & 25 & 1558.5 & 662.3 \\
\hline & 0 & -50 & 80 & 3.55 & 395 & 25 & 1558.5 & 662.3 \\
\hline
\end{tabular}

Table 6. Emission stack data for the three model runs in case of three stack.

\begin{tabular}{|c|c|c|c|c|c|c|c|c|}
\hline & \multicolumn{2}{|c|}{ Coordinate } & \multirow{2}{*}{$\begin{array}{c}\text { SH } \\
\text { m }\end{array}$} & \multirow{2}{*}{$\begin{array}{c}\text { SD } \\
\mathbf{m}\end{array}$} & \multirow{2}{*}{$\begin{array}{l}\mathbf{T} . \\
\mathbf{K}\end{array}$} & \multirow{2}{*}{$\begin{array}{c}\mathbf{V} \\
\mathbf{m} / \mathbf{s}\end{array}$} & \multirow{2}{*}{$\underset{\mathrm{S} / \mathbf{y}}{\mathrm{SO}_{2}}$} & \multirow{2}{*}{$\begin{array}{c}\mathbf{P M}_{10} \\
\mathrm{t} / \mathbf{y}\end{array}$} \\
\hline & $\begin{array}{l}\mathbf{X} \\
\mathbf{m}\end{array}$ & $\begin{array}{l}\mathbf{Y} \\
\mathbf{m}\end{array}$ & & & & & & \\
\hline \multirow{3}{*}{1} & 0 & 100 & 80 & 3.55 & 395 & 15 & 1558.5 & 662.3 \\
\hline & 0 & 0 & 80 & 3.55 & 395 & 15 & 1558.5 & 662.3 \\
\hline & 0 & -100 & 80 & 3.55 & 395 & 15 & 1558.5 & 662.3 \\
\hline 2 & 0 & 100 & 80 & 3.55 & 395 & 15 & 1558.5 & 662.3 \\
\hline
\end{tabular}

\begin{tabular}{|c|c|c|c|c|c|c|c|l|}
\hline & 0 & 0 & 80 & 3.55 & 395 & 15 & 1558.5 & 662.3 \\
\hline & 0 & -100 & 80 & 3.55 & 395 & 15 & 1558.5 & 662.3 \\
\hline \multirow{3}{*}{3} & 0 & 100 & 80 & 3.55 & 395 & 15 & 1558.5 & 662.3 \\
\cline { 2 - 8 } & 0 & 0 & 80 & 3.55 & 395 & 15 & 1558.5 & 662.3 \\
\cline { 2 - 8 } & 0 & -100 & 80 & 3.55 & 395 & 15 & 1558.5 & 662.3 \\
\hline
\end{tabular}

\subsection{Results and discussion}

Stack height and exit velocity are among the main dispersion controlling parameters. An increase in the stack height and exit velocity enhance effective plume rise and promotes buoyancy induced dispersion, resulting in a decrease in the maximum pollutant concentration. An increase in exit velocity decreases the maximum pollutant concentration as an increased plume momentum leads to a higher mixing and turbulent dispersion. For both $\mathrm{SO}_{2}$ and $\mathrm{PM}_{10}$ it was noted that there is considerable reduction in concentration as stack height increased from $80 \mathrm{~m}$ to $120 \mathrm{~m}$, and after that height, the concentration doesn't change significantly as shown in Figure 3 and Figure4.

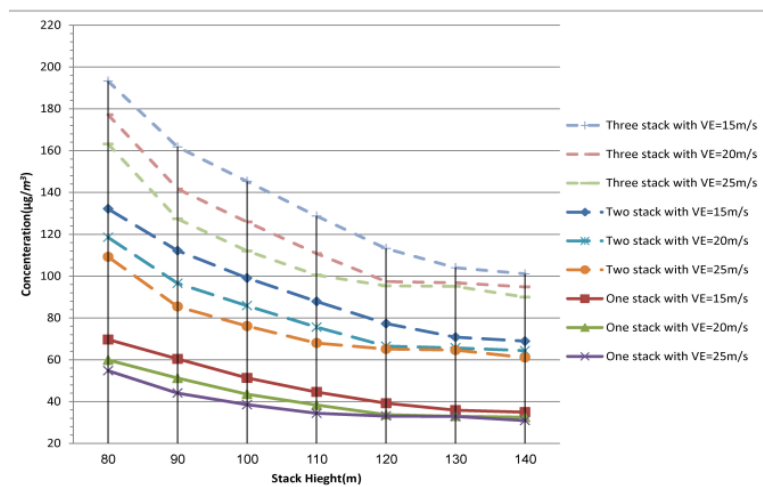

Figure3: Relationship between max hourly concentrations of $\mathrm{SO}_{2}$ generated from one, two and three stacks and stack height

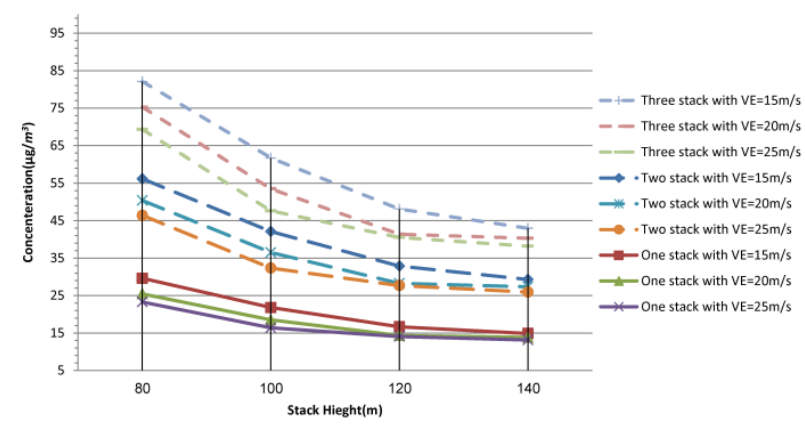

Figure4: Relationship between max hourly concentrations of $\mathrm{PM}_{10}$ generated from one, two and three stacks and stack height

\section{HELWAN CEMENT FACTORY}

The proposed cement plant is located $30 \mathrm{Km}$ south of Cairo. The Cement plant is located in an area of $1.000 .000 \mathrm{~m}^{2}$ with ten production lines (eight in operation). In Cement plant there are two dry lines and six wet lines (four in operation) for grey cement plus two wet lines producing white cement. The dry lines I and II were inaugurated in 1985 and 1987 respectively each designed to yield a maximum of 4200 ton of cement per day[10].

The plant is currently producing the following types of cement: 
1. CEM 42.5 R (according to norms EN 197-1 and ES 4756-1/2005)

2. SRC $42.5 \mathrm{~N}$ (according to norms ES 583/2005 and BS 4027/1996)

3. CEM I 42.5 R White Cement (according to norms EN 197.1 and ES $4756-1 / 2005$ )

\subsection{Applying Model (AERMOD):}

The model using AERMOD was built to predict Hourly and Daily concentrations of air pollutants $\left(\mathrm{SO}_{2} ; \mathrm{NO}_{2}\right.$ and $\left.\mathrm{PM}_{10}\right)$ emitted from a cement plant at different receptor points. The predicted concentrations of the air pollutants (without back ground concentrations) are compared with Egyptian and International Environmental Laws [8,11].

\subsubsection{Terrain Data:}

The terrain data is in the form of Digital Elevation Model (DEM) data that is available from the USGS-DEM (U.S. Geological Survey). The receptor grid has specified covering an area of 14 x 14 sq. km with 200 m resolution.

\subsubsection{Meteorological Data:}

The required meteorological parameters are derived from prognostic high resolution simulations using a regional Mesoscale Model for creating weather forecasts and climate projections ( MM5) model outputs and create the AERMOD meteorological input file by-passing the need for AERMET and thus any observational data requirement. MM5 model is integrated for the period $1^{\text {st }}$ January to $31^{\text {st }}$ March 2009 using time step of 60 seconds[8].

\subsubsection{Cement plant (Current Case eight lines):}

Firstly evaluated the aggregate air quality impacts of cement plant with only eight production lines(current case). The emission stacks data for eight production lines as shown in Table 7 [9].

Table 7. Emission stacks data for eight production lines.

\begin{tabular}{|c|c|c|c|c|c|c|c|c|c|}
\hline $\mathbf{N}$ & 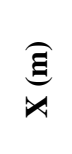 & 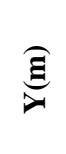 & $\underset{\widetilde{\Xi}}{\widehat{\Xi}}$ & 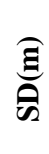 & $\underset{E}{6}$ & $\underbrace{\stackrel{\text { हn }}{\text { हn }}}_{>}$ & $\overbrace{\substack{\infty \\
0}}^{\sum_{0}^{\infty}}$ & $\frac{\widehat{\sigma}}{\underbrace{\infty}_{0}}$ & 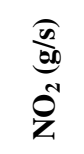 \\
\hline 1 & -100 & 140 & 95 & 3.5 & 122 & 13.5 & 21 & 49.42 & 21.30 \\
\hline 2 & -100 & 105 & 95 & 3.5 & 115 & 13.5 & 20 & 51.12 & 27.26 \\
\hline 3 & -100 & 70 & 95 & 3.5 & 135 & 13.5 & 20 & 49.42 & 24.20 \\
\hline 4 & -100 & 35 & 95 & 3.5 & 122 & 13.5 & 21 & 49.42 & 21.30 \\
\hline 5 & 0 & 165 & 95 & 3.5 & 150 & 27 & 8 & 52.82 & 24.71 \\
\hline 6 & 0 & 235 & 95 & 3.5 & 170 & 27 & 7 & 49.42 & 21.30 \\
\hline 7 & 400 & 35 & 90 & 3.5 & 141 & 13.3 & 20 & 6.00 & 26.24 \\
\hline 8 & 400 & 70 & 90 & 3.5 & 141 & 13.3 & 20 & 6.00 & 26.24 \\
\hline
\end{tabular}

\subsubsection{Result and discussions(eight production} lines)

Figure 6, Figure 7 and Figure 8 show the Max Hourly $\left(\boldsymbol{M}_{\boldsymbol{H}}\right)$ and Max Daily $\left(\boldsymbol{M}_{\boldsymbol{D}}\right)$ of $\mathrm{SO}_{2}, \mathrm{NO}_{2}$ and $\mathrm{PM}_{10}$ concentrations in the air during $\left(1^{\text {st }}\right.$ January to $31^{\text {st }}$ March 2009) for the emissions from stacks of cement plant.

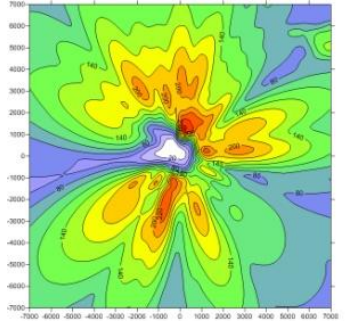

Figure6-a: $\mathrm{M}_{\mathrm{H}}$ of $\mathrm{SO}_{2}$

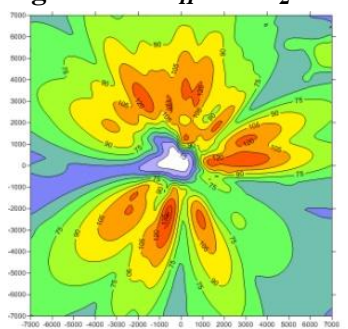

Figure7-a: $\mathrm{M}_{\mathrm{H}}$ of $\mathrm{NO}_{2}$

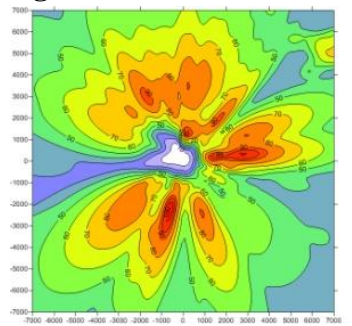

Figure8-a: $M_{H}$ of $\mathrm{PM}_{10}$

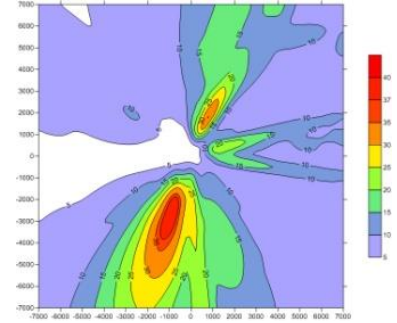

Figure6-b: $M_{D}$ of $\mathrm{SO}_{2}$

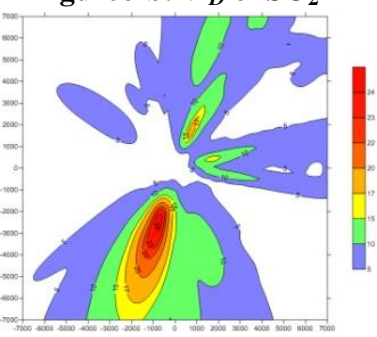

Figure7-b: $M_{D}$ of $\mathrm{NO}_{2}$

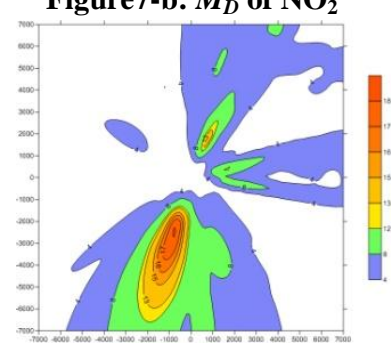

Figure8-b: $M_{D}$ of $\mathrm{PM}_{10}$
The emission concentrations from Cement plant (Current Case) were found to be less than the limits of International Environmental Laws as shown in Table 8.

Table 8. Maximum Emissions Concentrations when only eight lines operate

\begin{tabular}{|c|c|c|c|c|c|c|c|c|c|c|}
\hline \multirow[t]{2}{*}{ 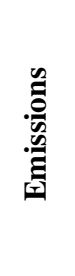 } & \multicolumn{2}{|c|}{ 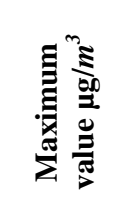 } & \multicolumn{2}{|c|}{ 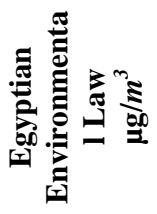 } & \multicolumn{2}{|c|}{ 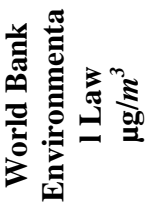 } & \multicolumn{2}{|c|}{ 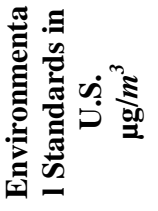 } & \multicolumn{2}{|c|}{ 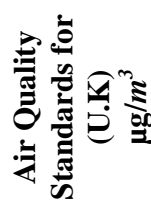 } \\
\hline & $M_{H}$ & $M_{D}$ & $M_{H}$ & $M_{D}$ & $M_{H}$ & $M_{D}$ & $M_{H}$ & $M_{D}$ & $M_{H}$ & $M_{D}$ \\
\hline $\mathrm{SO}_{2}$ & 295 & 46 & 350 & 150 & - & 150 & 435 & 365 & 350 & 125 \\
\hline $\mathrm{NO}_{2}$ & 149 & 25 & 400 & 150 & - & 150 & 200 & - & 200 & - \\
\hline $\mathrm{PM}_{10}$ & 115 & 19 & - & 70 & - & 150 & - & 150 & - & 50 \\
\hline
\end{tabular}

\subsubsection{Cement plant operate with full capacity (ten production lines)}

Secondly evaluated the aggregate air quality impacts of cement with full capacity (10 production lines).The emission stacks data for 10 production lines as shown in Table 9 [9].

Table 9. Emission stacks data for ten production lines.

\begin{tabular}{|c|c|c|c|c|c|c|c|c|c|}
\hline $\mathbf{N}$ & $\underset{x}{\Xi}$ & $\underset{ٍ ్}{\overparen{\Xi}}$ & $\stackrel{\overparen{\Xi}}{\widehat{\Xi}}$ & $\widehat{\overparen{\Xi}}$ & $\underset{E}{6}$ & $\underbrace{\widehat{D}}_{\vec{b}}$ & 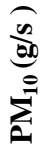 & 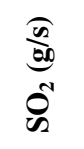 & 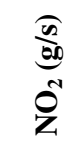 \\
\hline 1 & -100 & 140 & 95 & 3.5 & 122 & 13.5 & 21 & 49.42 & 21.30 \\
\hline 2 & -100 & 105 & 95 & 3.5 & 115 & 13.5 & 20 & 51.12 & 27.26 \\
\hline
\end{tabular}




\begin{tabular}{|c|c|c|c|c|c|c|c|c|c|}
\hline $\mathbf{3}$ & -100 & 70 & 95 & 3.5 & 135 & 13.5 & 20 & 49.42 & 24.20 \\
\hline $\mathbf{4}$ & -100 & 35 & 95 & 3.5 & 122 & 13.5 & 21 & 49.42 & 21.30 \\
\hline $\mathbf{5}$ & 0 & 165 & 95 & 3.5 & 150 & 27 & 8 & 52.82 & 24.71 \\
\hline $\mathbf{6}$ & 0 & 235 & 95 & 3.5 & 170 & 27 & 7 & 49.42 & 21.30 \\
\hline $\mathbf{7}$ & 400 & 35 & 90 & 3.5 & 141 & 13.3 & 20 & 6.00 & 26.24 \\
\hline $\mathbf{8}$ & 400 & 70 & 90 & 3.5 & 141 & 13.3 & 20 & 6.00 & 26.24 \\
\hline $\mathbf{9}$ & -100 & 0 & 95 & 3.5 & 122 & 13.5 & 21 & 49.42 & 21.30 \\
\hline $\mathbf{1 0}$ & -100 & 175 & 95 & 3.5 & 115 & 13.5 & 20 & 51.12 & 27.26 \\
\hline
\end{tabular}

3.Increase the exit velocity of gas emissions of all stack to $\mathbf{2 5}$ $\mathrm{m} / \mathrm{s}$ except stacks number five and six remain as previous $(27 \mathrm{~m} / \mathrm{s})$ the max concentration will decrease as shown in Table 10.

Table 9. Maximum Emissions Concentrations when

\subsubsection{Result and discussions (full capacity)}

Figure 9, Figure 10 and Figure 11 show the Max Hourly $\left(\boldsymbol{M}_{\boldsymbol{H}}\right)$ and Max Daily $\left(\boldsymbol{M}_{\boldsymbol{D}}\right)$ of $\mathrm{SO}_{2}, \mathrm{NO}_{2}$ and $\mathrm{PM}_{10}$ concentrations in the air during $\left(1^{\text {st }}\right.$ January to $31^{\text {st }}$ March 2009) for the emissions from stacks of cement plant.

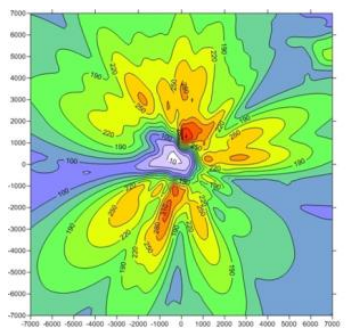

Figure9-a: $M_{H}$ of $\mathrm{SO}_{2}$

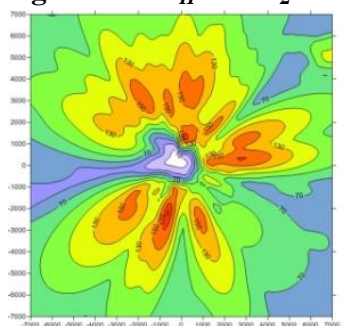

Figure10-a: $M_{H}$ of $\mathrm{NO}_{2}$

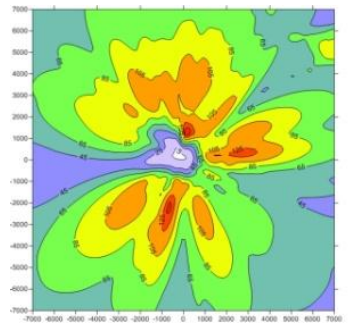

Figure11-a: $M_{H}$ of $\mathrm{PM}_{10}$

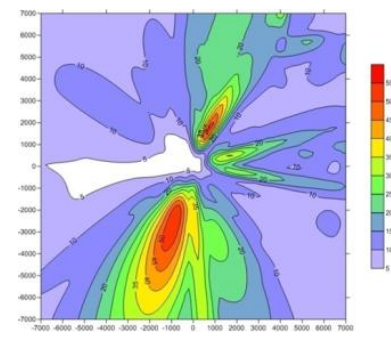

Figure9-b: $M_{D}$ of $\mathrm{SO}_{2}$

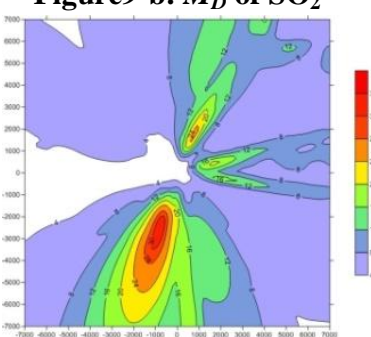

Figure10-b: $M_{D}$ of $\mathrm{NO}_{2}$

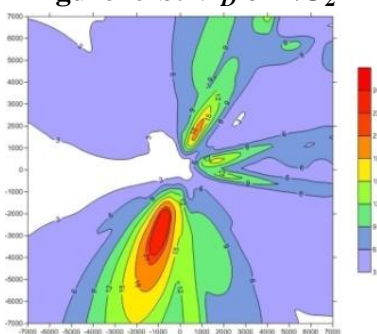

Figure11-b: $M_{D}$ of $\mathrm{PM}_{10}$

As shown in Table 9 concentrations of $\mathrm{NO}_{2}$ and $\mathrm{PM}_{10}$ ( without back ground concentrations) from the cement plant when operated with full capacity were found to be less than recommended by Egyptian and International Environmental Laws.

The emission concentration of $\mathrm{SO}_{2}$ based on $\left(M_{H}\right)$ is $\mathbf{4 1 2}$ $\mu \mathrm{g} / \mathrm{m}^{3}$ from the cement plant when operated with full capacity was found to be higher than the limits of Egyptian and International Environmental Laws.

There are several solutions to reduce the max hourly concentration of $\mathrm{SO}_{2}$ :

1. The cement plant operate as actual case with eight lines only not for ten lines

2. Reduction of $\mathrm{SO}_{2}$ emissions by

a. Reduce / homogenies $\mathbf{S}$ in inputs fuel and raw material

b. Using technical Filters. cement plant operate with full capacity

\begin{tabular}{|c|c|c|c|c|c|c|c|c|c|c|}
\hline \multirow[t]{2}{*}{ 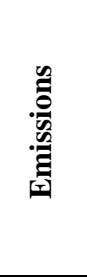 } & \multicolumn{2}{|c|}{ 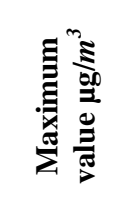 } & \multicolumn{2}{|c|}{ 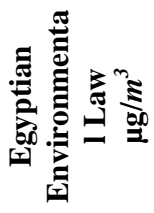 } & \multicolumn{2}{|c|}{ 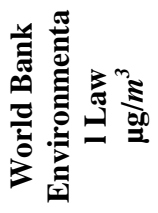 } & \multicolumn{2}{|c|}{ 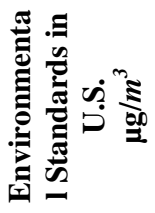 } & \multicolumn{2}{|c|}{ 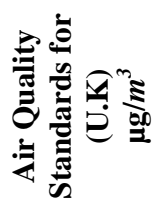 } \\
\hline & $M_{H}$ & $M_{D}$ & $M_{H}$ & $M_{D}$ & $M_{H}$ & $M_{D}$ & $M_{H}$ & $M_{D}$ & $M_{H}$ & $M_{D}$ \\
\hline $\mathrm{SO}_{2}$ & 41 & 63 & 350 & 150 & - & 150 & 435 & 365 & 350 & 125 \\
\hline $\mathrm{NO}_{2}$ & 195 & 32 & 400 & 150 & - & 150 & 200 & - & 200 & - \\
\hline $\mathbf{P M}_{10}$ & 158 & 25 & - & 70 & - & 150 & - & 150 & - & 50 \\
\hline
\end{tabular}

Table 10. Maximum Emissions Concentrations at exit velocity $25 \mathrm{~m} / \mathrm{s}$

\begin{tabular}{|c|c|c|c|c|c|c|c|c|c|c|}
\hline \multirow[t]{2}{*}{$\frac{\mathscr{\Xi}}{\mathscr{\Xi}}$} & \multicolumn{2}{|c|}{ 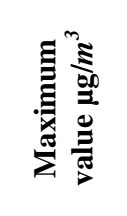 } & \multicolumn{2}{|c|}{ 氧 } & \multicolumn{2}{|c|}{ 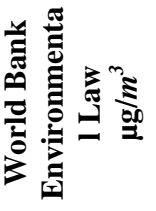 } & \multicolumn{2}{|c|}{ 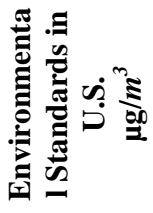 } & \multicolumn{2}{|c|}{ 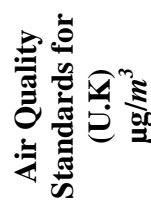 } \\
\hline & $M_{H}$ & $M_{D}$ & $M_{H}$ & $M_{D}$ & $M_{H}$ & $M_{D}$ & $M_{H}$ & $M_{D}$ & $M_{H}$ & $M_{D}$ \\
\hline $\mathrm{SO}_{2}$ & 312 & 48 & 350 & 150 & - & 150 & 435 & 365 & 350 & 125 \\
\hline $\mathbf{N O}_{2}$ & 160 & 27 & 400 & 150 & - & 150 & 200 & - & 200 & - \\
\hline $\mathbf{P M}_{10}$ & 120 & 20 & - & 70 & - & 150 & - & 150 & - & 50 \\
\hline
\end{tabular}

\section{CONCLUSIONS}

1. Stack height and exit velocity are among the main dispersion controlling parameters. An increase in the stack height and exit velocity enhance effective plume rise and promotes buoyancy induced dispersion, resulting in a decrease in the maximum pollutant concentration.

2. Applying stack heights up to $140 \mathrm{~m}$ height, it was found that stack height $120 \mathrm{~m}$ with exit velocity $20 \mathrm{~m} / \mathrm{s}$ was the optimum design parameter to reduce emission concentration.

3. The emission concentrations from cement plant (8lines) were found to be less than the limits of Egyptian and International Environmental Laws. However, the emission concentrations from the cement plant when operated with full capacity (10lines) were found to violate the limits.

4. In case of operating the factory with full capacity $(10$ lines), exit velocity should be increased to $25 \mathrm{~m} / \mathrm{s}$ except stacks number five and six remain as previous $(27 \mathrm{~m} / \mathrm{s})$, to match the allowable limits stated by Egyptian and International Environmental Laws. 


\section{REFERENCES}

[1] A. Josaa and A. Aguado, "Comparative analysis of available life cycle inventories of cement in the EU," in Cement and Concrete Research, 2007.

[2] L. M. N.S. Holmes "A review of dispersion modelling and its application to the dispersion of particles: An overview of different dispersion models available," in Atmospheric Environment, 2006.

[3] J. H. Seinfeld and S. N. Pandis, "Atmospheric chemistry and physics from air Pollution to Climate Change", Second ed.: John Wiley \& Sons, Inc., 2006.

[4] L. M. N.S. Holmes "A review of dispersion modelling and its application to the dispersion of particles: An overview of different dispersion models available," Atmospheric Environment, pp. 5902-5928, vol. 40, 2006.

[5] U.S.EPA, " AERMOD:Latest Features and Evaluation Results" vol. EPA-454/R-03-003: EPA, 2003.
[6] [21]EPA, ".User's Guide for the AERMOD Terrain preprocessor (AERMAP). ," Office of Air Quality Planning and Standards, Research Triangle Park, NC. , vol. (Docket No. A-99-05, II-A-4), 1998.

[7] U.S.EPA, Office of Air Quality Planning and Standards,Emissions Monitoring and Analysis Division, Research Triangle Park, NC 27711, "User's Guide for the AERMOD Meteorological Preprocessors (AERMET)," 2004.

[8] Egyptian Meteorological Authority.

[9] Egyptian Environmental Affairs Agency.

[10] Suez Cement: http://www.suezcement.com.eg.

[11] Egyptian Environmental Affairs Agency, "Environmental Impact Assessment Guidelines for Cement Manufacturing Plants": Ministry of State for Environmental Affairs,Egypt, 2005. 